\title{
Toward a Stark Utopia
}

Our thesis is that the idea of a self-adjusting market implied a stark utopia. Such an institution could not exist for any length of time without annihilating the human and natural substance of society; it would have physically destroyed man and transformed his surroundings into a wilderness. Inevitably, society took measures to protect itself, but whatever measures it took impaired the self-regulation of the market, disorganized industrial life, and thus endangered society in yet another way. It was this dilemma which forced the development of the market system into a definite groove and finally disrupted the social organization based upon it. (Polanyi 1944: 3-4)

On November 20, 2003, in the rural countryside of India, Nagalinga Reddy, a farmer of rice and sunflowers, committed suicide. At fifty years of age, Reddy took his life by ingesting ammonium phosphate tablets-a pesticide used in modernized farming. His rice crops had just failed due to pests and he was deeply in debt to usurious moneylenders, three banks, and a cooperative. He was harassed regularly by his creditors, and he finally put an end to their tyranny by taking his life. ${ }^{1}$ But Reddy's suicide was no isolated incident. Since 1995, there has been what can only be described as an epidemic of farmer suicides in India. The Hindu reports that from 1995 to 2010, 256,913 farmers have taken their lives-the vast majority by ingesting the very same pesticide swallowed by Reddy. ${ }^{2}$ According to the Center for Human Rights and Global Justice and P. Sainath, who has covered the epidemic in India, the common link between these 
suicides is punishing personal indebtedness to local moneylenders and/or microfinance institutions (2011: 1; Deshpande and Arora 2010; Young 2010; Taylor 2012). But the epidemic has another contributing factor: the neoliberal reforms introduced in India in 1991. To regain the confidence of creditors in its burgeoning budget and trade deficit as well as mounting national debt, the Indian government accepted neoliberal reforms in exchange for a loan from the International Monetary Fund (IMF) (Chossudovsky 2002: 149ff; McCartney in Saad-Filho and Johnston 2005: 238). ${ }^{3}$ To ensure debt service to rich creditors, economic reforms hit many agricultural communities particularly hard. Many farmers experienced mounting costs for energy and basic inputs like fertilizer. These goods were once subsidized by the government, but with the turn to neoliberal austerity in the 1990s, farming was increasingly financed through the personal debt of farmers and their families. This politico-agricultural transformation has led to land dispossession, the concentration of land in fewer hands, and widespread farmer suicides (Mohanty 2005; Levien 2011; 2012; 2013).

In the rural countryside of Thailand, we find another story of humanity in the global age. Nok is a woman raised in rural Thailand and a seemingly willful participant in her own trafficking to Japan. According to her own account, her father was deeply in debt to credit and agricultural cooperatives because the money the family made from rice farming was insufficient to repay the interest, let alone the principal. In this predicament, Nok's older sister had agreed to be trafficked to Japan in return for paying a debt of 3.5 million yen (about \$34,000) to her traffickers. She worked in the sex industry and eventually paid down her debt, enabling her to send more money back home. Nok soon followed in her sister's footsteps and used the same trafficker to become a sex worker in Japan (Aoyama 2009: 85ff). Like the farmer suicides of India, this is no isolated incident. Countless Thai women have been trafficked not only to Japan and surrounding region but also to brothels in their home country. The practice typically begins when a family is encouraged to sell their daughter to a broker who promises 
to get them cash work in the city. The transaction is too often made so that the family can use the money to overcome economic hardship (e.g., to repay mortgages on rice fields) and even acquire some of the trappings of modernity (e.g., television and electrical appliances). ${ }^{4}$ This begins what can only be called a debt trap:

The contractual arrangement between the broker and parents requires that this money be repaid by the daughter's labor before she is free to leave or is allowed to send money home. Sometimes the money is treated as a loan to the parents, the girl being both the collateral and the means of repayment. In such cases the exorbitant interest charged on the loan means there is little chance that a girl's sexual slavery will ever repay the debt. (Bales 2012: 41).

As Jefferies notes, this practice is not isolated to Thailand: "trafficking in women and girls into debt bondage is becoming the main method of supply for national and international sex industries. It is worth $\$ 31$ billion yearly according to UN estimates" (2009: 152).

The dismal epidemic of farmer suicides and sex trafficking have also corresponded with a rise in organ trafficking. Medical research and modern technology have made organ transplants more routine, potentially elongating and improving the lives of a lucky few who have access to donors and capable surgeons. But this medical advance also has a dark side. Poverty, debt, and desperation have helped fuel a growing international trade in human organs. The trade is often illicit but appears to be happening with increasing frequency among vulnerable populations (Scheper-Hughes 2000; Territo and Matteson 2011; Decker 2014). In rural Bangladesh, what Moniruzzaman (2012) calls a "body bazzar" has emerged to take advantage of mounting debt levels due to the microcredit revolution and the financialization of the countryside. Microcredit is the extension of small non-collateralbacked loans. The loans are made with the belief that the poor will use this money to become entrepreneurial and eventually better their economic and social conditions. While this revolution has been celebrated by many for lifting poor women and men out of 
poverty, it has also been heavily criticized for capitalizing the most vulnerable and creating mini-debt traps that can spiral out of control. For example, with the introduction of credit into rural Bangladesh, many Bangladeshis who have taken loans are finding it difficult to repay their creditors. Some, such as Mohammad Akhta Alam, were in debt to more than one nongovernmental organization specializing in microcredit. The more wealthy and educated take advantage of desperate debtors, who are mostly illiterate and uneducated, and convince them to sell one of their kidneys, liver lobes, or corneas. When Alam could not repay his debt, an organ broker persuaded him to sell one of his kidneys. In desperation, Alam accepted the offer and is now partially paralyzed and blind in one eye. He can no longer do any heavy lifting. What makes matters worse is the money Alam was promised was never paid in full-he received only a fraction of the total promised to him. In his own words, Alam says, "I agreed to sell my kidney because I couldn't return the money to the NGOs. As we are poor and helpless, that is why we are bound to do this. I regret it." Alam's experience is not unique. As Moniruzzaman's (2012) ethnography reveals, this type of "bio-violence" is increasingly common in Bangladesh. Although it is not always the case that people commodify their bodily organs for money to service their debts (some just do it for the extra money), debt has been a primary driver of the trade as identified in at least Brazil, Malaysia, Pakistan, India, Iran, Iraq, Indonesia, Israel, Egypt, Serbia, Philippines, Vietnam, Mexico, South Africa, the United States, and China.

In a world of increasing commodification, education itself has become a commodity increasingly capitalized by investors. Nowhere is this more true than in the United States, where students now collectively owe $\$ 1.2$ trillion to the US government and myriad banks and private lenders. The average student debt is $\$ 30,000$, with some students finishing their education with debt as large as $\$ 150,000$. Some will be able to service their debts and eventually repay them when they find decent employment. Many others, however, will have difficulty finding jobs with decent pay and hence struggle to service their interest-bearing loans throughout their lives. With few exceptions, 
student loans can never be discharged through bankruptcy and many may go to their graves still in hock for pursuing an education. In fact, crushing debt burdens have already influenced some to take their own lives and many more have daily thoughts of suicide. ${ }^{6}$ Others suffer from acute stress, anxiety, and depression. For its part, the US government is doing precious little, largely because of bipartisan bickering and the influence of the banking lobby on Congress. With 40 million students leaving college with debt, the United States is looking more and more like a debtocracy than a democracy. ${ }^{7}$

The Global Financial Crisis of 2007-8 was in reality a global debt crisis. Many nations are still affected, but the case of Greece is particularly stark for its social dislocations and violence. Kouvelakis (2011) has argued that the debt crisis in Greece must be understood within the historical trajectory of Greece's development that emerged after the dictatorship (1967-74). From 1981, successive administrations built up a social welfare state with a large public sector and generous entitlements such as jobs for life and generous pensions. The government also bought considerable military hardware from abroad and financed the 2004 Olympics construction. To pay for these projects, government elites borrowed from foreign creditors while many wealthy citizens underreported their income for tax purposes or evaded taxes altogether. From 1981 to 2007, the national debt ballooned from roughly 27 percent of gross domestic product (GDP) to 105 percent by the time of the crisis. In 2014 that figure stands at 153 percent of GDP. Eventually, this debt became unsustainable and forced Greece into the hands of the EU-ECB-IMF, commonly known as the troika. The overall assessment was that the population was living beyond its means, and in order to receive new loans to service the old ones, the government would have to enact severe cuts to its social spending. Public sector salaries and pensions were slashed and public assets sold off to raise funds to repay creditors-a pattern, as we shall see, that has been recurrent in previous national debt crises. Not surprisingly, political upheaval and social unrest soon followed as the population turned its anger toward elite corruption, kleptocracy, and foreigners. Multiple reasons have been given for the debt crisis, from corruption 
and tax evasion to a bloated public sector (Manolopoulos 2011). But one thing is certain: debt has led to a generalized politics of austerity with the most vulnerable suffering the most, as the Greek tragedy continues to unfold.

What unites these seemingly discrete moments of crisis and hardship that cut across both geographical space and historical time? Despite circumstantial differences, they are all social acts or practices that can be traced to the prevalence of debt. The world is awash in debt, and though we should recognize that debt levels and access to credit are radically unequal within and between countries, the commonality of all modern political economies is not so much that they are market oriented but that they are all debt-based political economies. Indeed, as Rowbotham noted, "the world can be considered a single debtbased economy” (1998: 159). To take an international perspective, according to the global management consulting firm McKinsey and Co., as of the second quarter of 2014 the total outstanding debt across 183 countries was $\$ 199$ trillion. ${ }^{8}$ In 1990 , the same figure was only $\$ 45$ trillion or a 342 percent increase over the period (McKinsey 2013). As identified in Table 1.1, since 2000 all categories of debt have increased considerably with government debt, financial industry debt, and household debt leading the categories.

Table 1.1 Total global debt by category

\begin{tabular}{lcccc}
\hline Type of debt & $\begin{array}{l}\mathbf{2 0 0 0}(4 Q) \\
\text { Dollar } \\
\text { (trillion) }\end{array}$ & $\begin{array}{l}\text { 2007 (4Q) } \\
\text { Dollar } \\
\text { (trillion) }\end{array}$ & $\begin{array}{l}\mathbf{2 0 1 4 ( 2 Q )} \\
\text { Dollar } \\
\text { (trillion) }\end{array}$ & $\begin{array}{l}\text { Percent } \\
\text { increase (\%) } \\
\text { since 2000 }\end{array}$ \\
\hline Government bonds & 22 & 33 & 58 & 163 \\
Financial bonds & 20 & 37 & 45 & 125 \\
Corporate bonds & 26 & 38 & 56 & 46 \\
$\begin{array}{l}\text { Household } \\
\text { Total debt as a }\end{array}$ & 20 & 33 & 40 & 100 \\
$\%$ of GDP & 246 & 269 & 286 & 16 \\
\hline
\end{tabular}

Source: McKinsey (2015: 15). 
But the concept and prevalence of debt in capitalist modernity needs to be critically theorized. Our starting point, and primary argument, is that debt within capitalist modernity is a social technology of power and its continued deployment heralds a stark utopia. Our claim is not that debt can be thought of as a technology of power but rather that debt is a technology of power. By technology, we simply mean a skill, art, or manner of doing something connected to a form of rationality or logic and mobilized by definite social forces. In capitalism, the prevailing logic is the logic of differential accumulation, and given that debt instruments far outweigh equity instruments, we can safely claim that interest-bearing debt is the primary way in which economic inequality is generated as more money is redistributed to creditors. In other words, debt instruments effectively divide society into debtors and creditors within a power structure that vastly privileges the latter over the former. However, we know this is a bold claim to make, but we hope by the end of this book, the reader will be convinced of our argument and inspired to learn more and take political action.

\section{A brief review of debt scholarship}

The literature on debt cuts across the social sciences and is relatively vast. For this reason we cannot hope to offer a comprehensive review of the literature. However, as it currently stands, the literature can be divided into major groupings that address different, albeit, interrelated concerns: (1) the origin of the national debt (Omond 1870; Denby 1916; Hamilton 1947); (2) debt within and throughout history (Geisst 2013; Graeber 2013; Kwarteng 2014); (3) the debt crises of the 1980s in the Global South (Payer 1974; George 1988; 1992; Griffith-Jones 1989); (4) the current sovereign debt crises of the Global North (Pettifor 2006; Chorafas 2011; Lane 2012; Greer 2014); (5) odious debt (Bonilla 2011; Manolopoulos 2011; Ndikumana and Boyce 2011); and (6) country-specific debt crises and struggles to find alternatives (Rowbotham 1998; Lin 2003; Brown 
2007; 2013; Bonner and Wiggin 2009; Dienst 2011; Soederberg 2012; 2013a; 2013b; Jackson and Dyson 2013; Pettifor 2014 ).

For the most part, these are all valuable contributions to our knowledge. However, our study seeks to cut across these boundaries to provide a more foundational, historically sensitive, and comprehensive theorization of debt as an interconnected global phenomenon. In this light, our book is unique for two main reasons.

First, rather than focus on the historical emergence of debt as a moral obligation, country-specific debt, or periodic financial crises related to debt, we are interested in the production of commercial money as debt under capitalism. We argue that under capitalism, debt is a technology of power, intimately connected with the control, creation, and allocation of modern money, the requirement for perpetual growth, and the differential capitalization that benefits what has recently, and aptly, been called "the 1\%"-particularly the owners of money-creating instruments (Di Muzio 2014). Thus, what we are interested in is how the control, production, and allocation of money as interest-bearing debt gets capitalized by private social forces and what this means for the majority of people on the planet. This is incredibly important since after oil and gas, banking is the most heavily capitalized sector on the planet, with the largest banks by market capitalization valued at $\$ 4.4$ trillion dollars (Di Muzio 2012). ${ }^{9}$ The owners or investors of these banks capitalize the banking sector's power to create money as interestbearing debt-the major source of the banking sector's profits. This is highly troublesome but not just for systemic risk and future financial crises, as the IMF has pointed out. ${ }^{10}$ When we consider the question of differential power, it is worrisome because of the following:

(1) We know that only a small minority of individuals and families own the majority of shares in publically listed banks and that this ownership is largely hidden from public scrutiny. ${ }^{11}$

(2) We know that the banking sector is highly interconnected with banks owning shares in each other as well as other corporations (Vitali et al. 2011). 
(3) The ability to create money as interest-bearing debt out of nothing is an incredible power that funnels money upward to the owners and executives of banks as they collect interest and fees on needed credit.

(4) Given that loans are contingent on creditworthiness and past wealth accumulation, there is always a hierarchy of access to money with the already rich having far easier access to credit and thus far more advantages to accumulate wealth.

(5) Democracy is held at ransom by the banks insofar as our elected governments have tacitly agreed to let private individuals and families capitalize the supply of money required for economic interdependence in a market economy. We historicize and elaborate on each of these points in the ensuing chapters.

The second reason this book is unique is that we follow Ingham (2004) and others (see e.g., Piketty 2014: 573ff) in recognizing that the ossified disciplinary boundaries that originated with the Methodenstreit are largely unhelpful if we want to understand the social relations of capitalism. For this reason, we approach our study with what we call an "interconnected historical holism." What we mean by this term is a mode of historical inquiry that begins with the recognition that the histories of human communities and their natural environments are interconnected in complex spatial and hierarchical relations of power. We suggest that to understand their development we need to examine not only the particularities of a given human community and their cultural practices but more importantly their interconnected, interdependent, and international dimensions (Bhambra 2007; 2010). Since all modern economies are debt economies, this leads us to a more holistic account of debt as a technology of power within capitalist modernity. Since debt under capitalism is increasingly ubiquitous at all levels of society and economic growth (and austerity) is now virtually the sole mantra of dominant political parties around the world, we argue that tracing some of the major inflections in the evolution and effects of debt as a technology of power is crucial for understanding 
the "present as history" and for suggesting possible alternatives to our current trajectory. But as Mann reminds us, "ubiquity, however, is not uniformity" (2003: 3). The hierarchy, meaning, and culture of indebtedness is not static, but a fluid continuum within and between political communities.

It is not our intent to do a review of the extensive literature, much of it recent, on debt and its impact. However, two highly publicized works relate directly to our work, one, David Graeber's Debt: A 5000 Year History, explicitly addressing debt, and the other, Thomas Piketty's Capital in the Twenty-First Century, implicitly addressing it and the distribution and creation of power over social reproduction (Bakker and Gill 2003). Given the magnitude and timeliness of both Graeber's book on debt and Piketty's on capital, it is important to show how our work is distinct from theirs and how they both inform our arguments.

Graeber's starting point seems to be how social obligations eventually turn into pecuniary debts that are quantifiable. From this point he stumbles upon power and argues that debts are typically enforced and facilitated by violence or the threat of punishment and that a market economy is largely the result of war, conquest, and slavery (2013: 385). But Graeber does not sufficiently theorize the power underpinnings of debt in a society governed by markets and the price system - power is not his starting point, but a supporting actor in a much larger 5,000-year historico-anthropology of debt. ${ }^{12}$ Unlike Graeber, our starting point is the presence of power as a differential social relation, and we theorize debt not just as money owed but as a technology of differential power over others rooted in private ownership. So whereas Graeber muses that "what makes debt different is that it is premised on an assumption of equality," we argue the exact opposite: the very foundation of modern capitalist debt is premised upon inequality or "differential power"our preferred term (2011: 86). This point leads us to consider, to our knowledge for the first time in this light, not just the private control over the production and allocation of money but its very ownership and capitalization. ${ }^{13}$ It is only from this starting point, we reason, that we can begin to think about debt within capitalist modernity in its 
interconnected and international dimensions. This is the second point of difference our work has with Graeber's erudite and impressive study: we do not offer a sweeping history of debt across millennia but have the far more modest goal of trying to understand the role of debt as a technology of power in the emergence and development of capitalist modernity. Of course, we recognize with Ingham's sympathetic critique of Graeber's work that "a long developmental sequence" was certainly involved in producing current levels and practices of debt (2013: 135). But while retracing millennia of human history may be intellectually stimulating, we reason with Polanyi ([1944] 1957) that capitalism was such a decisive break with previous forms of human economy that it warrants closer scrutiny than Graeber's study permitted. ${ }^{14} \mathrm{~A}$ third point of departure from Graeber's work is that in historicizing the emergence of capitalism we postulate an energy-debt-money nexus, whereby the expansion of the money supply through the creation of interest-bearing loans is assisted (not determined) by the surplus energy of fossil fuels (oil, coal, and natural gas). ${ }^{15}$ In other words, countries that have high levels of total final energy consumption will also be economies with large money supplies and mounting levels of debt. We find this empirically verifiable, and as such, our observations have important implications for the future of the global economy. A fourth distinction of this work is that we recognize the ecological dimension to our present debtmonetary order. The ecological dimension can be stated thus: the creation of money as interest-bearing debt is the motive force triggering the need for economic growth and an automatic progression in the destruction, despoliation, and commodification of the natural world of limited and finite resources. A final difference with our work from that of Graeber is that we offer solutions to the problems discussed in the book. Not knowing exactly how to proceed with his research findings, Graeber more or less throws his hands up in the air at the end of his study. ${ }^{16}$ Strangely, there is no proposed solution to some of the key problems he identifies other than praising the nonindustrious poor (2013: 390). ${ }^{17}$ Our analysis, however, not only differs from Graeber's in the ways identified above but also offers feasible solutions that can 
be debated by activists and policymakers alike, and a strategy through which these reforms can be implemented.

Piketty's much-publicized work derives largely from over 200 years of data on wealth distribution, compiled by him and his associates, that shows that wealth and income inequality, high in the nineteenth century, fell in the mid-twentieth century, but has risen again and, according to Piketty, will continue to rise throughout the twenty-first century absent any measures to prevent it. Capital purports to explain the reasons for this wealth trajectory, and, implicitly the distribution and accumulation of power.

The key to his work relates to the relationship between the rate of return on capital $(r)$ in an economy and its rate of economic growth $(g)$. When the rate of return on capital, that is, financial return in the form of profits, dividends, interest, rents, royalties, and other incomes from capital, exceeds the rate of growth, that is, the national income, capitalism will automatically generate "arbitrary and unsustainable inequalities" that violate the meritocratic values at the foundation of democratic societies (Piketty 2014: 1). He represents this relationship as $r>g$. For example, in 1910 the income of the top 10 percent of the income distribution constituted some 45-50 percent of the national income, declined to under 35 percent in 1970, but rose again to 50 percent in 2007, declining slightly since then as a consequence of the $2007 / 2008$ recession. Thus, since 1980, the top 10 percent of the income distribution appropriated three-quarters of income growth, the richest 1 percent received 60 percent, while the bottom 90 percent received less than 0.5 percent a year (Piketty 2014: 297). The same picture is true regarding wealth distribution. The top 10 percent, which owned between 60 and 80 percent of the wealth in the early nineteenth century, had its share of national wealth reduced to around 60 percent in the mid-twentieth century but now holds between 60 and 70 percent. In essence, Piketty demonstrates that the portion of national income that is owed to capital, that is, the return of profits, dividends, interest, rents, royalties, and so on, inexorably increases and presently claims some 30 percent of national income. 
There are a number of reasons why wealth and income distribution converged in the mid-twentieth century according to Piketty, but according to him the major factors were the two world wars and the Great Depression, which not only destroyed capital but also prompted governments to formulate economic policies that increased labor's share of the national income. Absent these shocks to capital and the subsequent reversal of government policies regarding public spending, wealth and income inequality have again diverged, creating the inequalities we see today.

Piketty's arguments are, obviously, more complex and require consideration of such things as the role of inherited wealth in the economy and the role of the rise of what he calls "super-managers" and their outsized salaries, and we will be addressing some of Piketty's findings throughout this book, but at this point it is useful to highlight aspects of his work that relate most directly to ours.

While Piketty does not address debt, per se (there is no index entry), the book is every bit as much about debt as is Graeber's. Simply put, for the economic books to balance, for every capital investment, that is, for every expected return on capital, whether it be in the form of a loan, rent, a stock purchase, a business investment, and so on, there must be a corresponding debt and someone or something that will generate the return. This has a number of important implications.

First, it essentially divides society into net creditors and net debtors. The difference between these two analytical categories is that somethe net creditors-receive more income from capital than they pay out, while others-the net debtors-pay out more in interest than they receive. By recognizing this division between net creditors and net debtors (as opposed to simply viewing it abstractly as "capital" or "return on capital"), we get a better sense of the extent to which the vast majority of the population must generate financial returns for a small minority.

The second major point to extract from Piketty's work is the fact that while capital has a present existence it is always future oriented, since the returns on capital are contingent on meeting present profit expectations 
in the future. In other words, the great unknown is whether returns on capital can be realized. Recall that the total global debt in 2014 was $\$ 199$ trillion; while we don't know exactly the expected return on that debt, nor the time period in which it must be paid, we do know that if future economic growth is insufficient, there can be dire consequences. Regardless, the future owes a debt to the present; capital has a claim on the future (or, as Piketty puts it, "the past devours the future") and the size of that claim obviously makes a big difference. Regardless, if, as Piketty shows, historical precedent is any indicator, capital will exercise a greater and greater claim on future income, and the question is whether economic growth will be sufficient to meet that claim, and, if not, where will capital attempt to realize or seize its expected return?

And this takes us to a third major point of Piketty's work: growth, he predicts, will slow and approach the historical average of 1.5-2 percent, while expected return on capital will remain at its historic average of 4-6 percent. Piketty doesn't explain, as we will try to do, why growth will slow, recognizing only that the growth rates of emerging economies will slow to that of rich countries, a phenomenon that economists refer to as "convergence"; but economists do recognize that the wealthier a country becomes, the more difficult increasing the rate of growth will be. But this fact has enormous import given the present and growing claim of capital, that is, creditors, on national income. So, what are the main factors inhibiting growth and the ability of the future to repay the past or debtors to repay creditors? We'll mention only two here.

First, economic growth is exponential, such that an economy growing at a 3 percent rate must essentially double every twenty-three years. Thus, if the global economy grew at 3 percent a year, by 2100 , as we will see, it would approach a quadrillion dollars. We will examine this limitation on growth in more detail in Chapter 4.

Second, economic growth is largely dependent on fossil fuel energy and this type of energy is a nonrenewable resource that is likely to increase in cost throughout the twenty-first century. In fact, our economy is essentially based on the transformation of energy (largely from fossil fuels but other sources as well) into money, and either a 
decline in the availability of energy or an increase in its cost will substantially hinder continued growth. In other words, our societies monetize energy flows and stores. While Piketty basically ignores the role of energy in the economy, as does Graeber, it may be no accident that the historical period of convergence of income corresponds to the period of plentiful and affordable oil.

If, then, the rate of growth slows, but capital investments, and consequently its inverse-debt-grows, how can capital's share of the national income be honored and defaults, bankruptcies, and financial chaos avoided? This is where the full consequences of debt as a technology of power can be appreciated.

If more and more income is owed to capital, which is almost all in private hands, and if the power of capital and debt supersedes all others, then capital's claim on future income will trump all other claims, regardless of moral or humanitarian consequences, a point that Graeber emphasizes. As we have seen in the past thirty years, and more recently during the economic contraction of 2007/2008, the claims of capital or creditors were the first honored, even if that required taxpayer bailouts, or the taking of money from other public resources (e.g., education health and welfare) or from labor's share of the national income. Quantitative easing is also a way in which the central banks in the capitalist core have tried to re-inflate the capital markets.

Unlike Graeber, who offers no solution, Piketty is far bolder. According to him, the only way we can avoid the problem is through a global tax on wealth. This, he says, will lower the claim of capital on national wealth and provide funds to minimize the damage. Such a utopian solution, he says, can only be accomplished through banking laws that make wealth holdings transparent. A number of countries, including Italy, Spain, and Sweden, have attempted this. The problem, as Italy discovered, is that without international laws, capital will simply flee to friendlier havens to escape the tax. The difficulty, of course, is persuading governments to consider such measures and examine whether this is the only solution, an issue we will return to in Chapter 5. 


\section{Arguments and structure}

As a technology of differential social power, debt is intertwined with local and global social struggles with interconnected and international implications for the future of the global economy. This book makes a series of interrelated arguments around this general claim. First, debt, and its inverse credit, can be theorized as a major technology of power known by its effects on social relations and environmental change. The main purpose of debt has not been so much to enable debtors; instead it has been, more importantly, to disable them from engaging in certain practices that would find them outside the orbit of the world market of differential accumulation. Capitalist debt helps to produce market-based subjects (Mahmud 2012: 469). Second, as the institution of exclusive private property advanced by violence and legal sanction, debt was mobilized in a more systematic and intensified manner by those in the control of credit in order to shape and reshape the terrain of social reproduction for the sake of the symbolic accumulation of power represented in money. Third, there is a transition to the modern, organized control of credit/debt with the birth of the national debt and the extension and amplification of state bureaucracy, taxation, standing armies, and over time, the private capitalization of banking or money creation. Fourth, by the twentieth century, credit/debt largely becomes depersonalized and corporatized so that a small number of investors have come to capitalize evermore aspects of human endeavor and natural resources through their ownership of banks and financial instruments. Fifth, the present magnitude and globalization of debt would not have been possible without the exploitation of abundant, affordable, and accessible fossil fuels. In other words, the exploitation of a surplus energy source permitted some of humanity to delink themselves from the austerity of organic economies with lower surpluses. However, as fossil fuel energy becomes evermore expensive in the twenty-first century, we are likely to experience more intensive debt crises at all levels of society and across political boundaries, as 
more of people's disposable income is transferred to those in control of the energy that they require to socially reproduce their lifestyles. Sixth, modern money, created largely as interest-bearing debt, spurs the need for economic growth, with drastic social, cultural, and environmental consequences that are leading to evermore social dislocations and dire environmental consequences such as the loss of biodiversity, deforestation, desertification, and global climate change. Seventh, in the twentieth century, debt becomes more connected to a culture of materialism and conspicuous consumption, whereby people are encouraged and conditioned to self-actualize through the purchase of advertised commodities (Gill 1995). Eighth, current levels of debt imply what Polanyi called a "stark utopia": the belief that the modern system of money created as interest-bearing debt can continue ad infinitum on a finite planet. So long as our political and business leaders continue to cling to this false utopia of endless money-debt and growth, transitioning to a saner, more equitable, and environmentally sustainable world will be near impossible. Last, there is a need not only to interpret the present situation and to understand it historically but also to change it to ensure the well-being, if not the survival, of humanity. Moreover, for those who believe in democracy - that the people should have a say in their own governance- it is imperative that the public claims ownership over the control of money and manufacturers it in such a way that will avoid crippling debt and the redistribution of wealth upward. Building on the outcomes of our study, we offer a way in which this might be addressed through a Party of the $99 \%$ and a political strategy that uses debt itself as a means to promote change; we consider also how we might imagine ways of decapitalizing a near-universal but radically unequal sociality of debt that has emerged and intensified with the private capitalization of the power to create and allocate money as interest-bearing debt.

To examine these claims in more detail, we have organized the remainder of this book into four chapters organized by theme: the modern origins of capitalist debt, how debt as a technology of power was intensified historically, the consequences of modern 
debt, and what is to be done. We provide a brief summary of each to conclude this introduction.

In Chapter 2 we investigate the modern origins of debt as a technology of power by focusing on war, the creation of the "national" debt, and the capitalization of the organized force of the state. We trace the origins of debt as a technology of power to a confluence of events in seventeenth-century England. However, far from seeing this as a series of discrete events untainted by international interconnections, we theorize them as already embedded in a web of dynastic, geopolitical, and domestic relations of force. The purpose of founding the national debt in England - which was war-is already stamped with the financial machinations of the Dutch empire, Italian city-states of the fourteenth and fifteenth centuries, the Atlantic slave trade, and the conquest of North America and India by capitalized joint-stock companies such as the East India Company. The main argument in this chapter is that the invention of a funded long-term national debt was principally born not to finance wars to aggrandize the power of the Crown per se but more importantly to aggrandize the power of what Justin Rosenberg (1994) has called "the empire of civil society"-or to be more accurate, those members in civil society with the means and mentality to accumulate money, not the unpropertied, pauperized masses. The way we approach this account of the rise of debt as a technology of power is to understand it from the point of view of the powerful who came to capitalize the state by effectively owning private shares in the government's right to tax its citizenry (Marx 1887; Nitzan and Bichler 2009: 294ff). But since the state's primary function at this time was warmaking, the capitalization of the state meant that investors were also capitalizing the ability of the state to mobilize its organized violence to quell domestic dissent and open and keep open colonies and trade routes. With this in mind, we must also be concerned to illustrate how the capitalization of joint-stock companies contributed to debt and the transformation of human relations and the environment as merchants pursued differential earnings outside of England, and after the Acts of Union (1707) in Britain. 
In Chapter 3 we use the term "intensification" rather than spread or proliferation to think about both the amplification and spatial expansion of debt as a technology of power during the era of European colonialism and resistance. Once again we start from the point of view of the powerful - of superior force and violence in the quest for differential accumulation. Here, we examine how imposing imperial taxation regimes or what we call "imperial monetization" (always backed by force and punishment) contributed to displacing modes of life not connected up with the international market of price and profit. Unlike Graeber and Braudel, we do not see the market as something separate from capitalism but the very precondition for the emergence of capitalization and debt as a technology of power (Nitzan and Bichler 2009). As numeric computational power processes, capitalization and debt can only work through price, and where contracts, transactions, activities, and so forth cannot be priced, bought, and sold, capitalization and debt as technology of power cannot operate. Put another way, the market is not a space outside of capitalization or debt but the chief enabling mechanism for the accumulation of differential power represented in money. We then move to examine how "national" debts were created and administered in the colonies, the impact decolonization movements had on these historical structures, and the major events leading up to the debt crisis of the 1980s in what today is referred to as the Global South. We conclude the chapter with an examination of the sovereign debt crisis in the so-called heartland of global capitalism or what Pettifor (2006) has called the "coming first world debt crisis."

In Chapter 4 we examine the consequences of debt as a technology of power at both the macrolevel (e.g., environmental destruction, inequality of wealth, and life chances) and microlevel (e.g., the re-emergence of debtor prisons in the United States and the disciplining of indebted subjects). With these two levels in mind, we explore three major consequences of the private capitalization of money as interestbearing debt.

The first major consequence is that the creation of money as debt requiring interest requires evermore economic growth and therefore 
the greater and more rapid exploitation of natural resources. There are three chief obstacles to this pursuit, and why continuing to believe the present system can replicate itself in perpetuity implies blatant utopic thinking: (1) the planet is finite and we are exhausting many of our resources at an accelerated pace, (2) fossil fuels are nonrenewable and their combustion contributes excessively to global warming/dimming, and (3) there has never been an example of continuous exponential growth on earth.

A second consequence is that our creation of money through loans/ debt, where the interest is never created, means that there is always more debt in the system than there is the ability to repay it. For example, when a bank extends a loan of $\$ 1,000$ dollars at 10 percent interest, it does not create the money to pay that interest-which would be $\$ 100$. Put simply, the bank creates $\$ 1,000$ not $\$ 1,100$. So the question must be, where the interest comes from? The only possible solution is that the interest must come from the principal itself-meaning there is never enough money in the system to clear all debts. In this sense, the source of debt as a technology of power for creditors lies in its very permanence.

A third consequence is the intensification of neoliberalism and austerity measures in various countries experiencing higher levels of debt to GDP ratios, not to mention capital flight and tax evasion (e.g., Greece). Here we examine the impact of austerity measures and the growth of debt levels and how they affect citizens of indebted nations as well as those in developed countries. We will also re-examine Thomas Piketty's work and suggest that he neglects to consider the role of debt in the increasing income and wealth gaps that he documents, and we will illustrate the extent to which debt serves as a device of wealth transfer. Finally, to demonstrate the extent to which debt as a technology of power has colonized our lives, we'll examine the question of who, under the existing political economy, controls our future.

Having considered the consequences of debt as a technology of power in Chapter 4, in Chapter 5 we examine what should and can be done about debt in the current conjuncture. Our first argument is that a Party of the $99 \%$ with a specific party platform is a useful starting point 
for thinking about resistance to the present debt order. Our second argument focuses on using debt itself to force the decapitalization of the present monetary order so that a small minority cannot capitalize the labor of others or the world's natural resources for their own symbolic accumulation. In this regard, it is important to realize that, while debt is a technology of power, and that creditors exercise an inordinate amount of control over debtors, the wealth of the $1 \%$ lies largely in the pockets of the $99 \%$ where it must work to generate ever-increasing returns for the dominant owners of capital. 
Tim Di Muzio and Richard H. Robbins - 9781526101013 Downloaded from manchesterhive.com at $04 / 26 / 2023$ 11:19:58AM 